\title{
Mature stand developmental stage has ceased to constitute the most suitable habitat for the capercaillie in the Augustów Forest, Poland
}

\author{
Stanisław Drozdowski ${ }^{1}$, Dorota Zawadzka ${ }^{2}$, Grzegorz Zawadzki ${ }^{*}$ (D), Marcin Studnicki ${ }^{3}$ and Bogdan Brzeziecki ${ }^{1}$
}

\begin{abstract}
Background: Forest management affects the habitat conditions for many forest-dwelling species. Among them, the capercaillie (Tetrao urogallus) is a rare forest grouse inhabiting old, mature forests. We compared the structure of forest habitat among 9 active and 9 abandoned leks in the Augustów Forest (North-Eastern Poland), within a radius of $1 \mathrm{~km}$ of the leks, defined as the Key Areas for the capercaillie in lowland temperate forest. Habitat measurements were conducted on 1779 circular plots. Assessments made on all plots related to 13 habitat variables measured or noted in the field, including stand structure, canopy closure, stand developmental stage, percentage of Scots pine (Pinus sylvestris), soil fertility and soil moisture, the share of undergrowth, the cover of shrubs, the cover of bilberry (Vaccinium sp.), and the presence of certain habitat elements important to the capercaillie.

Results: To compare the still-occupied and the abandoned KAs for the capercaillie, a logistic regression model was developed. The variables best explaining differences between these two categories were: the occurrence of undergrowth layers, canopy closure in the second canopy layer, and stand age. According to the model, with the increase of the shrub-layer cover as well as the density of trees, the probability of the presence of the capercaillie decreased. The capercaillie in the area of the Augustów Forest occupy mainly dry and poor, middle-aged, pinedominated forests, with a moderate extent of stand canopy closure and only weakly-developed layers of undergrowth.

Conclusions: The filling-in of mature stands with sub-canopy trees and shrubs (the process which is stimulated by climate change and site eutrophication) causes structural changes, which are unfavourable to the capercaillie. This might explain why in the course of the recent decades the capercaillie has abandoned the oldest stands, distinguished by the presence of bigger shares of undergrowth. The capercaillie has shifted to younger stands, which reveal a lesser extent of canopy closure and a more limited development of understorey vegetation.
\end{abstract}

Keywords: Habitat suitability, Lek occupancy, Logistic regression, Lowland forest, Stand structure, Tetrao urogallus

\footnotetext{
* Correspondence: grzegorz_zawadzki@sggw.edu.pl

${ }^{1}$ Institute of Forest Sciences, Warsaw University of Life Sciences,

Nowoursynowska 159, 02-776 Warszawa, Poland

Full list of author information is available at the end of the article
}

\section{Springer Open}

(c) The Author(s). 2021 Open Access This article is licensed under a Creative Commons Attribution 4.0 International License, which permits use, sharing, adaptation, distribution and reproduction in any medium or format, as long as you give appropriate credit to the original author(s) and the source, provide a link to the Creative Commons licence, and indicate if changes were made. The images or other third party material in this article are included in the article's Creative Commons licence, unless indicated otherwise in a credit line to the material. If material is not included in the article's Creative Commons licence and your intended use is not permitted by statutory regulation or exceeds the permitted use, you will need to obtain permission directly from the copyright holder. To view a copy of this licence, visit http://creativecommons.org/licenses/by/4.0/. 


\section{Background}

Forest management has a profound impact on forest habitat conditions (Angelstam 1996; Battles et al. 2001). It leads to forest fragmentation, the disappearance of a forest's natural structure, the shortening of the stand developmental cycle, and a reduction of the area of oldgrowth stage (e.g. Angelstam et al. 2004; Lõhmus et al. 2005; Zawadzka et al. 2016). Other effects include a reduction of the volume of dead wood as well as an elimination of natural disturbance patterns and structures (Linder and Östlund 1998; Lindenmayer and McCarthy 2002; Bujoczek et al. 2018). Birds are an important group of organisms affected by forest practices in many different ways (Scheringer and Schumacher 2004; Basile et al. 2019). The birds which are most sensitive to habitat changes are highly-specialised species, especially those connected with mature forests (Rosenvald and Lõhmus 2003; Roberge and Angelstam 2006; Czeszczewik et al. 2014; Zawadzka et al. 2018). The maintenance and conservation of forest biodiversity, including rare bird species, is one of the significant challenges of modern forestry (Basile et al. 2016).

In Europe, one of the most endangered forest bird species is the capercaillie Tetrao urogallus, which is considered an iconic species serving an "umbrella" role (Pakkala et al. 2003; Lõhmus et al. 2017). The capercaillie is a rare sedentary forest grouse species that lives in the old, natural forest complexes of a larger size, occurring in certain boreal and mountainous regions of Europe (Storch 2001, 2007; Jahren et al. 2016). It has proved to be among the birds which are most sensitive to the anthropogenic changes of forest habitat, not least due to a large amount of living space required by both individuals and the whole populations of this species (Rolstad and Wegge 1987; Angelstam 2004; Angelstam et al. 2004; Wegge and Rolstad 2011). The global climate warming can also have a negative impact on the grouse population (Moss et al. 2001; Storch 2007; Poirazidis et al. 2019). As a result of the anthropogenic pressure related to habitat loss, forest management, and hunting, the last two centuries witnessed the species' retreat from large parts of both Western and Central Europe (Tomiałojć 2000).

Population declines among capercaillies have, in fact, been observed in almost all European countries for some time now. However, the process has been most rapid in the central and southern parts of the species' fragmented European range (Zawadzka and Zawadzki 2003; Storch 2007). The capercaillie is listed in Annex 1 of the EU's Birds Directive, and is also Red-Listed as an endangered species - and under strict protection - in 21 European countries, including Poland (Głowaciński 2001; Storch 2007).

Capercaillie extinctions and population declines are both associated with habitat loss and fragmentation, as well as intensified land-use by people (e.g. in sport, tourism and recreation, and forest management) (Storch 2007, 2013; Thiel et al. 2011; Moss et al. 2014; Coppes et al. 2017, 2018). The major reasons for changes in the habitat of the species are considered to relate to the development of commercial forestry, where large areas are clear-felled (Saniga, 2003; Wegge and Rolstad, 2011; Mikoláš et al., 2015; Kämmerlea et al. 2020). The remaining areas of old-growth forests are too small and isolated, and extensive areas of young and middle-aged stands are characterised by unsuitably high densities of trees (Sirkiä et al. 2011). In general, the negative influences of forestry manifest mostly in the destruction of lekking sites along with the surrounding territories occupied by males, as well as, partly, in overall habitat loss and forest fragmentation (Rolstad and Wegge 1987; Miettinen et al. 2010; Wegge and Rolstad 2011; Mikoláš et al. 2015). Changes in the structure of forest landscape, induced by forest management, affect the distribution of leks and the area occupied by the capercaillie (Angelstam 2004; Zizas et al. 2017). Besides the direct influences (such as clearcutting in lek areas), modern forestry has affected populations of the capercaillie also in an indirect manner, namely through its tendency to cause change in forest structure, age, and stand composition (Broome et al. 2014; Braunisch et al. 2019). In forests which are managed, natural disturbances - characteristic of unmanaged old-growth forests that do favour the formation of a forest structure suitable for the capercaillie - play only a minor role (Mikoláš et al. 2017). The widespread fencing of forest plantations results in grouse collisions. Locally, it can represent an important cause of mortality, as is the case in Scotland (Baines and Summers 1997). Collisions with fences as a cause of mortality of the capercaillie have also been documented in Poland (Zawadzka 2014).

In the Carpathian Mountains, selective logging at low intensity was reported as affecting the population of the local capercaillies in a positive way. In contrast, the proportion of forest clear-cuts in an area as well as the intensity of tourism are both seen to exert a significant negative influence on the numbers of males present at leks (Mikoláš et al., 2015).

In recent decades, several studies have made it clear that lekking is not at all confined to areas of a mature forest (Rolstad et al. 2007). The occurrence of the capercaillie is seen to be conditioned not only by the specific stand structure in the area of the lek, but also by the quality of forest habitat analysed on the landscape scale (Storch 2002; Sirkiä et al. 2011; Brzeziecki et al. 2012; Zizas et al. 2017).

The identification of habitat requirements of the capercaillie is a precondition for its effective conservation. The same can be said about the co-existing species, 
whose needs are less demanding but which benefit from the conservation measures adopted with regard to the capercaillie, which makes it a recognised umbrella species (Suter et al. 2002; Pakkala et al. 2003). Recently, studies on forest grouse, mainly the capercaillie, has focused on the ecological requirements, particularly habitat preferences (Moss et al. 2010). Inadequate attention to the capercaillie's habitat requirements is among the reasons for failures to achieve an effective reintroduction of the species (Merta et al. 2015).

Studies of habitat preferences have been conducted in order to determine the probability of the occurrence of the capercaillie. Work has also been done on areas occupied by still-relatively-large populations (Storch 2002; Braunisch and Suchant 2007; Teuscher et al. 2011), as well as by ones heading for extinction (Graf et al. 2005, 2007; Bollmann et al. 2011; Mikoláš et al., 2015). There are two emerging approaches to the assessment of habitat for capercaillies. In mountainous areas of Central Europe, the main kind of work uses mathematical modelling to identify habitat features associated with the highest probabilities of the species being present (e.g. Storch 2002; Bollmann et al. 2005, 2011; Braunisch and Suchant 2007; Graf et al. 2005, 2006, 2007; Teuscher et al. 2011). In Fennoscandia and the Baltic countries, there have been analyses of the long-term influence of structural change induced by forest management on the distribution of leks and changes in numbers of the birds (Gregersen and Gregersen 2008; Miettinen et al. 2010; Sirkiä et al. 2010, 2011; Wegge and Rolstad 2011; Leivitis 2014; Lõhmus et al. 2017; Zizas et al. 2017).

In the work presented here, the emphasis has been put on a detailed investigation of the habitat requirements of the species, which has been assessed in relation to the small and isolated natural population (of ca. 50-80 individuals) still living in the lowlands of North-Eastern Poland, in the managed part of the Augustów Forest. Based on the long-term monitoring of the capercaillie on the leks (Zawadzki and Zawadzka 2008, 2012), a total of 18 leks (9 active and 9 abandoned) were selected for field measurements. We investigated hierarchy and importance among 13 variables characterising the forest habitat within a 1-km radius of each of those 18 leks. At the latter stage, we considered the absolute and relative significances of each of the above variables, using a logistic regression with regard to the current status of leks within the managed forest as either abandoned or still occupied.

We hypothesised that changes in habitat structure at the stand scale were the key reason for the disappearance of the capercaillie from some locations in the Augustów Forest. Our expectation was that the identification of the importance of particular habitat features might prove to be useful in formulating recommendations concerning the active protection of habitat suitable for the capercaillie in the context of modern forestry. Moreover, the recognition of the most important variables characterising stand structure would help to determine the probability of the occurrence of species in any particular part of the forest. Our study would, therefore, offer indirect help with the assessment of the impact of forest management and other factors on the capercaillie's habitat conditions, at the same time providing a basis for recommendations concerning habitat management.

\section{Materials and methods Materials \\ The study area and data collection}

The Augustów Forest is the home of one of the country's four isolated populations of the capercaillie. The Polish part of the Augustów Forest is located in the north-eastern part of the country (at $23^{\circ} 15^{\prime} \mathrm{E}, 53^{\circ} 54^{\prime} \mathrm{N}$, Fig. 1) and extends over $1140 \mathrm{~km}^{2}$. The area is fairly flat, with a range of elevations between 135 and $190 \mathrm{~m}$ a.s.l. The climate is relatively cold, with a mean annual temperature of $6.5^{\circ} \mathrm{C}$, a 135 -day growing season, and snow cover typically present for around 100 days a year. Forest cover here is of around 93\%, while lakes account for a further $6 \%$ of the area. Tree stands are dominated by Scots pine (Pinus sylvestris) (78\%), Norway spruce (Picea abies) (8\%), black alder (Alnus glutinosa) (9\%), silver birch (Betula verrucosa) (5\%), and pedunculate oak (Quercus robur) (1\%). The understorey is formed mainly by spruce, while the bush layer consists mainly of young spruces and common junipers (Juniperus communis), with the cover of these varying from one stand to another. The mean age of tree stands here is 65 years, with stands older than 100 years accounting for about $15 \%$ of the overall area of forest. The mesic pine forest site type, distinguished by a big share of bilberry (Vaccinium myrtillus), accounts for almost $40 \%$ of the area, while $27 \%$ is occupied by mesic mixed coniferous forest site type with bilberry and bush-grass (Calamagrostis epigeios). Some $7 \%$ of the forest area is classified as a wet alder forest. The Augustów Forest is included in Europe's Natura 2000 network as the Special Protection Area for Birds PLB200002 "Puszcza Augustowska". Most of the area comprises managed stands supervised by six Forest Districts of Poland's State Forests National Forest Holding. Over the past several hundred years, this forest has been intensively managed with the use of a clear-cutting system. Clear-cuts were regenerated by either natural seeding (by leaving seed trees) or by direct seeding and/or planting. The study area has not been impacted by major natural disturbances, with these affecting small areas at most (Reindl 1965; Sokołowski 2010).

Data on the locations of lekking sites within the Augustów Forest, history of each lek and number of 


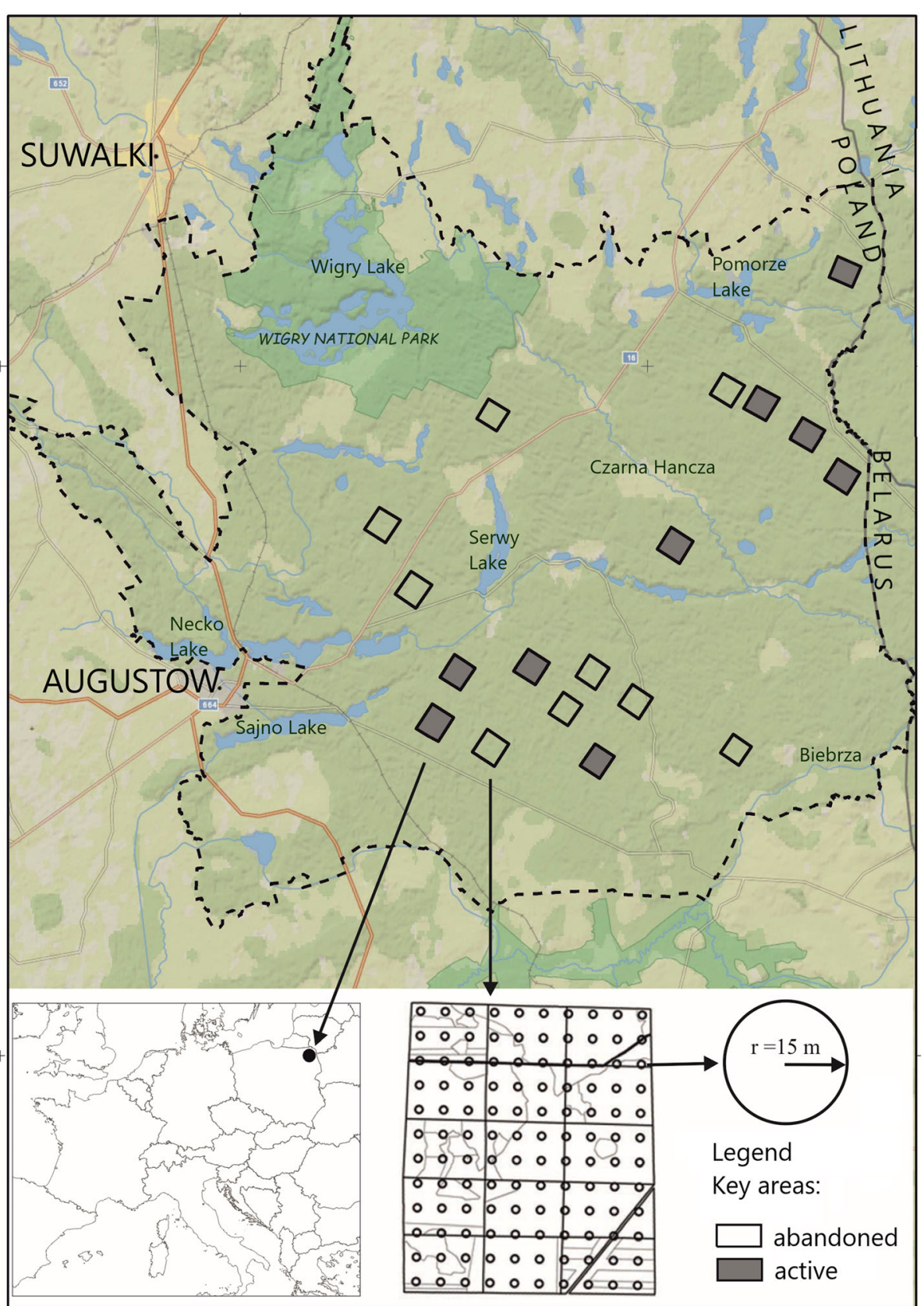

Fig. 1 Study areas in the Augustów Forest (North-Eastern Poland). Black points - active Key Areas around leks, open points - abandoned Key Areas around leks. The area of the whole square is ca. $4 \mathrm{~km}^{2}$. The measurements were conducted on circular plots $(r=15 \mathrm{~m}$ radius, located across a $200 \mathrm{~m} \times 200 \mathrm{~m}$ grid)

cocks attending, as well as on their present status (occupied or abandoned) was taken from Zawadzki and Zawadzka (2008, 2012). The spatial distribution of leks and the number of displaying cocks were determined during the 15-years-long monitoring. Every spring all known leks were visited three times in order to determine the number of capercaillie males (Zawadzki and Zawadzka 2008, 2012). The main fieldwork was carried out in the area of 9 active leks as well as 9 abandoned by the capercaillie over the last 25 years (6 less than 10 years ago). The study plots covered key areas located within a 1-km radius from the studied leks (Fig. 1). This size of the key area was recognised as a territory of the utmost importance for the proper functioning of the capercaillie population (Wegge and Larsen 1987; Wegge et al. 2013).

The assessment of the habitat was performed within the Key Areas, on circular plots positioned across a 200 
$\mathrm{m} \times 200 \mathrm{~m}$ grid (Fig. 1). Each plot had a radius of $15 \mathrm{~m}$ and thus covered $706 \mathrm{~m}^{2}$. We established between 53 and 133 study plots in each Key Area (depending on the local conditions, e.g. clear-cuts area, dense young plantations, roads), with the average amounting to 98; the area was spread over $4 \mathrm{~km}^{2}$. We excluded areas of open water and bogs. The nine Key Areas including active leks were represented by a total of 1032 circular plots, while there were 747 plots in the 9 Key Areas associated with abandoned leks.

\section{Stand and site variables}

Measurements or estimations made on all plots included 13 habitat features (variables) (Table 1). The description of the tree stand involved a determination of its age (ATS), tree stand structure (vertical layering) (TSS), stand density (TN), and the percentage share of Scots pine (PSP). Other recorded features included the canopy (crown) closure of the upper stand layer (CCUL) and the closure of the second stand layer (CCSL) as a measure of the amount of light penetrating through to the forest floor. The canopy closure was determined by the visual estimation from the ground - summing up the crown areas for all trees on a fixed plot area and dividing them by the ground area. We used a 5 -rank scale: Open $(1 ; 0-$ $30 \%$ of ground covered by crowns), Loose $(2 ; 31 \%-50 \%)$, Discontinuous (3; 51\%-70\%), Moderate (4; 71\%-90\%), Full $(5 ;>91 \%)$. Other measured or assessed variables included the classes of soil-moisture (SM) and soil fertility (SF), the shrub cover (PCS), the bilberry cover (PCB), the height of ground-vegetation $(\mathrm{GVH})$, the distance from roads used to transport timber (DFR), and the presence of specific habitat elements (PHE). In the latter case, we considered the occurrence of: 1) large trees with horizontal branches (good for perching); 2) dead fallen trees; and 3) anthills. Values for the analysed features on scales - as detailed in Table 1 - were estimated and noted in the field, with the information contained in the BDL forest data bank (available at https://www.bdl.lasy. gov.pl/portal/mapy-en) also being used.

The values of some explanatory variables (the share of Scots pine, tree stand structure, canopy closure, the cover of shrub layer, the cover of bilberry, ground vegetation height, and distance from roads) obtained ranks that increased with greater magnitudes of the given feature (e.g., the greater the percentage of the cover of bilberry, the higher the designated rank - Table 1). In this way, the importance of a higher level of a given parameter for the suitability of the habitat for the capercaillie was reflected. In the case of stand age, soil moisture, and soil fertility, values were given to labels based on the measured features of the stand that had been inventoried in the sample plots. These were chosen in such a way as to point to the characteristic habitat conditions associated with the phase of forest development (sapling, pole, early mature, mature forest, late mature), as well as trophic (oligo-, meso-, eutrophic) and moisture (dry, fresh, wet, bog) conditions of the soil. Thus, for example, stand aged between 1 and 10 years corresponded with the developmental phases of a young plantation, while an age over 100 represented a mature forest. There was, therefore, a correspondence with the structure characteristic of a given age-related developmental stage (Table 1). It was assumed that these variables would be nominal in nature. The assignment of different values to labels describing habitat features (variables) was based on

Table 1 Variables used to describe the capercaillie's habitat in the Augustów Forest

\begin{tabular}{|c|c|}
\hline Parameter [Acronym] & Value (rank or label) \\
\hline Age of tree stands (years) [ATS] & $1-10(1), 11-30(2), 31-60(3), 61-100(4),>100(5)$ \\
\hline Tree stand structure [TSS] & One-layered (1), Two-layered (2), Multi-layered (3) \\
\hline Percentage share of Scots pine (\%) [PSP] & $<20(1), 20-50(2), 50-70(3), 70-90(4),>90(5)$ \\
\hline Canopy closure of the upper layer [CCUL] & $\begin{array}{l}\text { Open }(1 ; 0-30 \% \text { of ground covered by crowns), Loose }(2 ; 31 \%-50 \%) \text {, Discontinuous }(3 ; 51 \%-70 \%) \text {, } \\
\text { Moderate }(4 ; 71 \%-90 \%) \text {, Full }(5 ;>91 \%)\end{array}$ \\
\hline Canopy closure of the lower layer [CCLL] & $\begin{array}{l}\text { Open }(1 ; 0-30 \% \text { of ground covered by crowns), Loose }(2 ; 31 \%-50 \%) \text {, Discontinuous }(3 ; 51 \%-70 \%) \text {, } \\
\text { Moderate }(4 ; 71 \%-90 \%) \text {, Full }(5 ;>91 \%)\end{array}$ \\
\hline Percentage cover of shrub layer (\%) [PCS] & $<10(1), 10-20(2), 20-40(3), 40-60(4),>60(5)$ \\
\hline Ground vegetation height $(\mathrm{cm})[\mathrm{GVH}]$ & $<10(1), 10-20(2), 20-30(3), 30-40(4), 50-60(5), 60-70(7), 70-80(8),>80(9)$ \\
\hline Percentage cover of bilberries (\%) [PCB] & Absence (1), 1-10 (2), 10-20 (3), 20-30 (4), 30-40 (5), > 40 (6) \\
\hline Soil moisture [SM] & Dry (1), Fresh (2), Wet (3), Bog (4) \\
\hline Soil fertility [SF] & Oligotrophic (1), Mesotrophic (2), Eutrophic (3) \\
\hline Distance from roads (m) [DFR] & $<10(1), 10-50(2), 50-100(3), 100-150(4),>150(5)$ \\
\hline Presence of habitat elements [PHE] & Absence (1), one element present (2), two elements present (3), three elements present (4) \\
\hline $\begin{array}{l}\text { Number of trees with diameter of } \\
\geq 7 \mathrm{~cm}(\mathrm{~N} / \mathrm{ha})[\mathrm{TN}]\end{array}$ & Range from 0 to 16,000 trees per hectare \\
\hline
\end{tabular}


information in the literature as well as on expert knowledge relating to the habitat requirements of the capercaillie.

\section{Methods}

First, the distribution of sample plots in classes corresponding with the occupied and abandoned Key Areas was compared using the $\chi^{2}$ test. Subsequently, the occupied and abandoned Key Areas were compared by means of logistic regression, with a binary dependent variable taking on values 0 (area abandoned) or 1 (area occupied). This method was used because of the fact that logistic regression does not set out assumptions regarding the nature of explanatory variables (which can be either ordinal or nominal). Moreover, the distributions of independent variables (assessed features of the forest) do not have to conform to a normal distribution (Kleinbaum et al. 1982; Hosmer and Lemeshow 1989). Binary logistic regression is a common statistical method used in conservation biology to estimate probabilities of occurrence in relation to different predictors (Kleyer et al. 1999; Cowley et al. 2000).

The general logistic regression model was:

$$
\operatorname{Logit}(Y)=\alpha+\beta_{1} X_{1}+\beta_{2} X_{2}+\ldots+\beta_{k} X_{k}
$$

where $Y$ is the dependent variable, $X_{i}(i=1-k)$ are the independent variables, $\alpha$ is the intercept, and $\beta_{i}$ are the coefficients.

In order to avoid a strong multicollinearity between predictor variables, we studied the correlation matrix for 10 out of 13 predictors (after excluding the three nominal variables: stand age, soil moisture, and soil fertility) (Table 2). If there was a strong correlation between two variables (Spearman rank correlation, $\left|r_{\mathrm{s}}\right|>0.70$ ), only that parameter which is seemingly more important for the species (in line with the literature and expert knowledge) was selected for further modelling (see Hosmer Jr and Lemeshow, 1989). The first analysis used all the non-co-linear explanatory variables. It was followed by the identification of a subset of explanatory variables characterised by the greatest predictive power, i.e., those assessed features of forest which were differentiating between occupied and abandoned KAs in the most adequate manner. We applied the Akaike Information Criterion to the selection of variables (Akaike 1974; Burnham and Anderson 2002), while general model performance was assessed by calculating the area under a receiver operating characteristic curve (AUC), as well as model sensitivity and specificity (Hanley and McNeil 1982). We carried out all statistical modelling with the R 3.6.1 packages stat and lme4, using a generalised linear model (GLM) for binary response variable ( $\mathrm{R}$ Core Team 2019).

\section{Results}

Habitat differences between active and abandoned leks The distribution of sample plots for age classes shows that in both categories of Key Areas stands over 30 years old occurred most frequently (Fig. 2a). In the Key Areas still occupied by the species, stands aged 30-60 years were prevailing. In contrast, the abandoned Key Areas were dominated by forest stands older than 60 years $\left(x^{2}=23.95 ; p=0.002\right)$. In the studied Key Areas, singlelayered stands dominated, while two-layered stands were limited (Fig. 2b). Stands in active and abandoned Key Areas differed in terms of structure $\left(\chi^{2}=27.05 ; p<\right.$ 0.001 ), with the occupied ones dominated by singlelayered stands.

Occupied Key Areas showed bigger shares of stands with more than $90 \%$ Scots pine $\left(\chi^{2}=21.99 ; p=0.002\right)$ (Fig. 2c). Canopy closure of the upper stand layer resembled a normal distribution (Fig. 2d). Abandoned stands have a higher canopy closure than occupied stands $\left(\chi^{2}=\right.$ 28.57; $p=0.001)$. Stands within active Key Areas have

Table 2 Spearman Rank correlation matrix for variables describing the capercaillie's habitat (Relationships statistically significant at $a=0.05$ are indicated by the use of italics strong correlation (Spearman rank correlation, $\left|r_{s}\right|>0.70$ ) between two variables is indicated by the use of bold)

\begin{tabular}{|c|c|c|c|c|c|c|c|c|c|c|}
\hline Description variables & TSS & PSP & CCUL & CCSL & PCS & GVH & PCB & DFR & PSE & $\mathrm{TN}$ \\
\hline TSS & - & -0.122 & -0.265 & 0.973 & 0.082 & -0.015 & 0.075 & -0.052 & 0.066 & 0.023 \\
\hline PSP & & - & 0.032 & -0.105 & -0.145 & -0.123 & 0.080 & 0.014 & 0.012 & 0.029 \\
\hline CCUL & & & - & -0.254 & -0.153 & -0.241 & -0.295 & -0.044 & -0.192 & 0.436 \\
\hline CCSL & & & & - & 0.088 & -0.020 & 0.075 & -0.060 & 0.057 & 0.038 \\
\hline PCS & & & & & - & 0.272 & 0.308 & -0.113 & 0.097 & -0.176 \\
\hline GVH & & & & & & - & 0.323 & 0.042 & 0.158 & -0.262 \\
\hline PCB & & & & & & & - & -0.029 & 0.184 & -0.310 \\
\hline DFR & & & & & & & & - & 0.080 & -0.014 \\
\hline PSE & & & & & & & & & - & -0.183 \\
\hline TN & & & & & & & & & & - \\
\hline
\end{tabular}




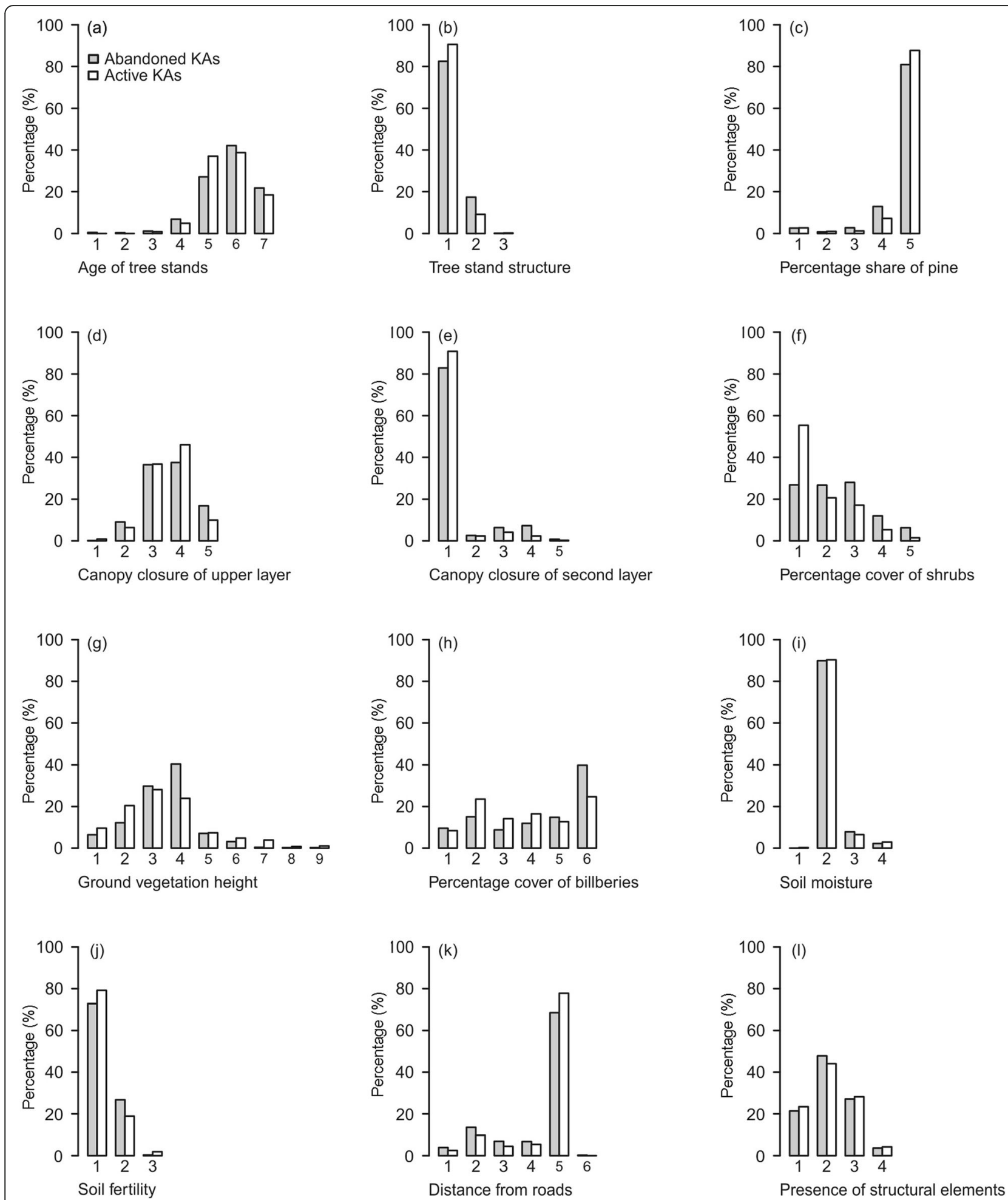

Fig. 2 Percentage shares of sample plots in still-occupied or abandoned refuges for variables (Table 1) describing Key Areas for the capercaillie

mainly a single-layered structure $\left(\chi^{2}=28.57 ; p=0.001\right)$, while the share of stands with a well-developed second layer was bigger in the abandoned Key Areas $\left(x^{2}=34.58\right.$; $p<0.001$ ) (Figs. 2e, 3a, 3b).
The occurrence of shrub and ground-vegetation layers was skewed to the left (Fig. 2f), meaning that undergrowth was, most typically, only poorly-developed in the Key Areas. Areas with only a poorly-developed shrub 


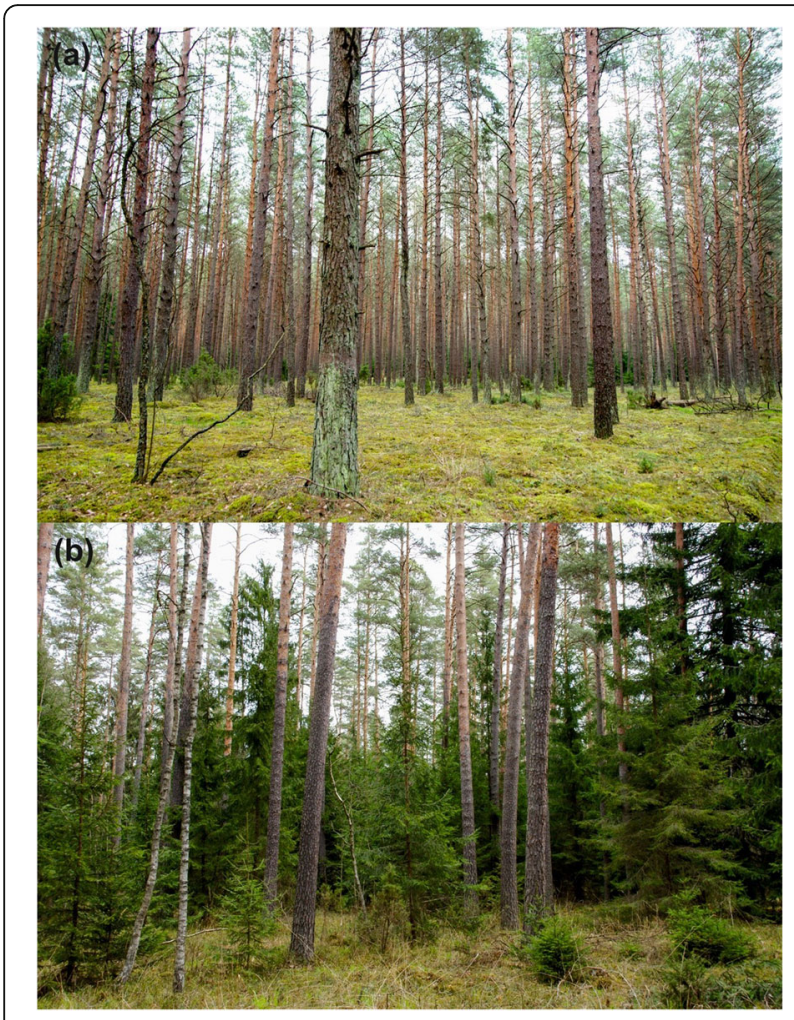

Fig. 3 The comparison of stand structure in Key Areas that are active (a) or abandoned (b)

layer occurred much more often in the still occupied Key Areas $\left(\chi^{2}=34.58 ; p<0.001\right)$. On most of the plots, ground vegetation did not exceed $40 \mathrm{~cm}$ in height. However, the height interval $30-40 \mathrm{~cm}$ was mostly present in the abandoned Key Areas $\left(\chi^{2}=94.72 ; p<0.001\right)$, while the still-occupied ones were dominated by shrubs, whose height was below $30 \mathrm{~cm}$ (Fig. 2g). The occupied Key Areas featured the prevalence of bilberry cover shares between $1 \%$ and 30\%, while the abandoned Key Areas featured the share of bilberry cover that often exceeded $30 \%\left(\chi^{2}=65.2098 ; p<0.001\right)$ (Fig. 2h). Mesic forest site types occurred most often in both occupied and abandoned Key Areas $\left(\chi^{2}=4.16 ; p=0.245\right)$, while the link between the age-class structure and soil humidity proved very similar in both variants (Fig. 2i). A somewhat greater share of nutrient-poor site types characterised the stilloccupied Key Areas, as opposed to the ones abandoned by the capercaillie $\left(\chi^{2}=21.96 ; p<0.001\right)$ (Fig. 2j).

We have found that distance from frequently used forest roads points to the prevalence of plots at a distance (> $150 \mathrm{~m}$ ) among the still-occupied Key Areas, as opposed to the abandoned ones $\left(\chi^{2}=20.34 ; p=0.001\right)$ (Fig. $2 \mathrm{k}$ ).

The numbers of special habitat elements proved to be similar in areas representing both categories $\left(\chi^{2}=3.03\right.$; $p=0.387$ ) (Fig. 2l). Nevertheless, it was noteworthy that
$33.2 \%$ of sample plots featured all these three structural elements identified as important to the capercaillie.

The numbers of trees with $\mathrm{DBH} \geq 7 \mathrm{~cm}$ per hectare were in the range from 0 (i.e., no such trees on plots located in newly-established plantations) to around 16,000 per hectare among the abandoned Key Areas, and to some 14,300 in the occupied ones. Nonetheless, respective mean values were of just 844 and 876 trees $\mathrm{ha}^{-1}$. All that can be said about this feature is that it proved to be more variable in plots representing the Key Areas abandoned by the capercaillie, as opposed to the stilloccupied ones ( $V=118 \%$ and $101 \%$, respectively).

\section{The logistic regression model}

Our inspection of the habitat correlation matrix revealed a very high correlation between stand structure and canopy closure of the second stand layer $(r=0.97)$. This ensured a limitation of further analysis to canopy closure of the second stand layer (Table 2).

The first parametrisation involved the full model containing all non-collinear variables, with the aim being to determine the influence of each explanatory variable on the modelled phenomenon. It emerged that higher values for canopy closure of the upper and the second layer, the cover of shrubs, the cover of bilberry, and stand density were associated with a reduced probability that a Key Area would still be found to be occupied by capercaillies, whilst higher values for proportion of Scot pine, the height of ground vegetation, distance from roads, and the presence of habitat elements were all associated with a higher probability of the Key Area being occupied (Table 3). In the case of the variable describing a forest's developmental stage, and with the mature stage chosen as a point of reference, capercaillies were categorised as less likely to be present in newly-planted areas and in young plantations and stands in the polewood stage, whereas they were more likely to occur in stands aged $30-60$ or $60-100$ years. A particularly high value for OR was obtained for stands that were 30-60 years old, with capercaillies being 1.6 times as likely to be present there as in the mature stage.

The reference variants for soil moisture and soil fertility were taken to be the wettest (boggy) soil and the soil of the highest fertility, respectively. Lower moisture and/ or fertility were associated with a higher probability of the presence of capercaillies. The chance (OR) of the species being present in the forest on dry soil was 2.4 times as high as in the reference conditions, while the corresponding figure was even 7.3 times as high where soil was poorer in nutrients, as opposed to the most fertile one (Table 3 ).

In fact, the model has six explanatory variables that achieve statistical significance, i.e., the stand age, the share of Scots pine, upper canopy closure, the cover of 
Table 3 Results of a logistic regression analysis - full model including all explanatory variables but stand structure

\begin{tabular}{llllll}
\hline Effect & Estimate & Standard Error & Wald Stat. & $\boldsymbol{P}$ & OR \\
\hline Intercept & 0.879 & 0.833 & 1.300 & 0.254 & 2.021 \\
ATS1 & -1.110 & 0.685 & 4.292 & 0.002 & 0.330 \\
ATS2 & -0.168 & 0.223 & 3.074 & 0.002 & 0.846 \\
ATS3 & 0.479 & 0.137 & 5.560 & 0.001 & 1.614 \\
ATS4 & 0.083 & 0.130 & 2.681 & 0.005 & 1.086 \\
ATS5 & Reference & & & & \\
PSP & 0.101 & 0.070 & 2.482 & 0.012 & 1.065 \\
CCUL & -0.204 & 0.081 & 6.883 & 0.009 & 0.622 \\
CCSL & -0.422 & 0.149 & 7.613 & 0.006 & 0.441 \\
PCS & -0.583 & 0.035 & 107.304 & $<0.001$ & 0.111 \\
GVH & 0.019 & 0.046 & 0.194 & 0.660 & 0.874 \\
PCB & -0.169 & 0.032 & 23.184 & $<0.001$ & 0.621 \\
SM1 & 2.280 & 1.090 & 0.040 & 0.968 & 2.410 \\
SM2 & 0.160 & 0.380 & 0.422 & 0.673 & 1.173 \\
SM3 & 0.580 & 0.429 & 1.354 & 0.176 & 1.787 \\
SM4 & Reference & & & & \\
SF1 & 4.218 & 1.215 & 0.342 & 0.652 & 7.237 \\
SF3 & 2.456 & 0.943 & 1.133 & 0.214 & 3.519 \\
SF3 & Reference & & & & \\
DFR & 0.069 & 0.041 & 2.276 & 0.131 & 0.953 \\
PSE & 0.033 & 0.062 & 0.214 & 0.643 & 0.965 \\
TN & -0.004 & 0.001 & 0.305 & 0.581 & 0.874 \\
\hline & & & & &
\end{tabular}

shrubs, and the cover of bilberry. The variables best distinguishing between the occupied and the abandoned Key Areas for the capercaillie proved to be shrub layer $(\mathrm{OR}=0.111)$ as well as the extent of the closure of the second canopy layer $(\mathrm{OR}=0.441)$. Only a slightly less considerable influence was found to be exerted by the stand age. The full model is characterised by high values for the ROC area beneath the curve (AUC $=0.72)$, with a high degree of specificity (73.3\%), although with low sensitivity (18.9\%) (Table 4).

In order to determine the optimal model - containing the variables that are best able to distinguish between Key Areas still occupied or else abandoned by capercaillies - all the combinations of subsets of explanatory variables were analysed. The model characterized by the lowest value for the AIC criterion was made up of following variables: the stand age, upper canopy closure, the cover of shrubs, and the cover of bilberry (Table 5). It further emerged that the variables of the greatest discrimination power involved the presence of the two layers of undergrowth (shrubs and ground vegetation)?) $(\mathrm{OR}=0.325)$, the closure of the second canopy layer $(\mathrm{OR}=0.369)$, the closure of the upper layer $(\mathrm{OR}=$ 0.565), and stand age as a manifestation of a developmental stage (Table 5). A greater cover by the lower stand layer and a higher density of trees in either the first or the second layer had a negative effect on the suitability of the habitat. Hence the chance of capercaillies being present in stands aged 30-60 years was 1.8 times as high as in the case of the mature forest, whereas it was lower in stands aged $60-100$ or $10-30$ years, and the lowest at all in newly-established plantations (Table 5). The cover of bilberry was also the subject of a significant relationship $(\mathrm{PCB}, \mathrm{OR}=0.687)$. The share of an occupied area accounted for by bilberry was often lower than on plots already abandoned. All the explanatory variables forming part of the optimal model achieved statistical significance. The optimal model was characterised by the presence of the AUC - an area under the ROC curve of 0.709 , with a very high level of specificity (91.9\%), but very limited sensitivity (5.3\%) (Table 6). This, in turn, ensures that the model offers a very clear indication of places with features of the biotope suitable for the capercaillie.

\section{Discussion}

The capercaillie has been commonly recognised as a bird species which needs different successional forest stages, but which prefers old, mature stands (Rolstad and Wegge 1987; Klaus et al. 1989; Storch 2001). Stands suitable for the capercaillie are characterised by a loose or moderately-dense canopy cover, a well-developed layer of bilberry bushes covering the ground, the presence of patches of trees regenerating naturally, as well as the occurrence of small open areas (Storch 2001, 2002).

Field-based observations of the active and the abandoned Key Areas - supported by the results obtained by the means of the logistic model as well as other studies from the Augustów Forest (Brzeziecki et al. 2012; Zawadzka et al. 2018) - suggest that capercaillies present there occupy mainly single-layered, poor coniferous stands, with an intermediate canopy cover, strongly dominated by Scots pine, and a very limited admixture of spruce. In the active Key Areas, the cover of shrub

Table 4 Confusion matrix for the full model $(\mathrm{OR}=3.35$, $\log \mathrm{OR}=1.21), 1$ - Key Areas still occupied by the capercaillie (active), 0 Key Areas abandoned by the species

\begin{tabular}{lllll}
\hline Observed & Predicted $\mathbf{1}$ & Predicted $\mathbf{0}$ & Percentage of correct observations \\
\hline 1 & 830 & 194 & Specificity & 73.35 \\
0 & 556 & 202 & Sensitivity & 18.94 \\
\hline
\end{tabular}


Table 5 Results of a logistic regression analysis - model parametrised by the method of searching all the possible combinations using the AIC criterion

\begin{tabular}{llllll}
\hline Effect & Estimate & Standard Error & Wald Stat. & $\boldsymbol{P}$ & OR \\
\hline Intercept & 1.993 & 0.614 & 10.545 & 0.001 & 3.254 \\
ATS1 & -6.105 & 1.422 & 3.529 & 0.004 & 0.400 \\
ATS2 & -0.936 & 0.304 & 3.571 & $<0.001$ & 0.793 \\
ATS3 & 4.113 & 0.201 & 3.195 & 0.001 & 1.812 \\
ATS4 & -0.011 & 0.159 & 3.748 & $<0.001$ & 0.983 \\
ATS5 & Reference & & & & \\
CCUL & -0.236 & 0.067 & 7.179 & 0.007 & 0.565 \\
CCSL & -0.443 & 0.060 & 47.347 & $<0.001$ & 0.369 \\
PCS & -0.428 & 0.059 & 117.157 & $<0.001$ & 0.325 \\
PCB & -0.217 & 0.024 & 29.481 & $<0.001$ & 0.687 \\
\hline
\end{tabular}

layer rarely exceeded 10\%, while in the abandoned Key Areas this level was, on average, much higher. Another finding, and a rather surprising one, concerned the preference for fresh coniferous forest site types. Over the last 20 years, the capercaillies living in the Augustów Forest have, indeed, abandoned the Key Areas located in moist or swamp coniferous forest site types, while all the leks remaining active at the time of our study were located in mesic pine forest sites. The only exception involves an old and extensive swamp pine forest, which has been in use by capercaillies for more than 90 years now (Domaniewski 1933; Zawadzki et al. 1999).

Both the full and the optimal logistic regression models were characterised by rather high levels of explanatory or predictive power, to the extent that they might be used to indicate areas more or less suitable for the species - e.g., with regard to the proposed efforts to resettle or reintroduce capercaillies - as well as management-related considerations as to where forests continue to fit in in terms of their economic usefulness. Specificity values proved to be particularly high (at 92\%), indicating a great extent of suitability of the model when it comes to an appropriate habitat being identified. In contrast, the model sensitivity was much lower, which is to say that it is far less efficient at rejecting sites or, to be more precise, at pointing to those places that are not suitable for the capercaillie.

We explored the capercaillie's habitat preferences within a 1-km radius. According to Storch (2002), such an approach, lacking characterisation at the landscape level, does not offers full opportunities for the quality of the capercaillie's habitat to be assessed. Nevertheless, our results confirmed the hypothesis that changes in the habitat observed at the patch scale can represent important reasons for capercaillies to abandon some leks in the Augustów Forest. It results that by far the most important factors (differentiating most clearly between occupied and abandoned Key Areas) are linked to a forest's vertical structure. Particularly, the presence of dense undergrowth has significantly reduced the probability of the occurrence of the capercaillie. The developed logistic regression model indicated that the filling of space in the forest with trees and shrubs - and hence an increase in overall stand volume - is inferred to do a lot to reduce the probability that capercaillies will be present. Such features are, of course, closely connected with forestry management in temperate forests, in which a high stocking rate is regarded as essential to both productivity and even the technical quality of trees producing timber (Oliver and Larson 1996). With this in mind, it is either the case that underplanting takes place in forests, or efforts are made to nurture the naturally-occurring undergrowth (Silvicultural Guidelines, 2012). In addition, installed or naturally-developing layers of undergrowth in nutrient-poor (oligotrophic) sites - such as the poor pine forest sites present in the Augustów Forest - are being stimulated anyway both by the global climate warming and by the ongoing habitat eutrophication. In the case of the Augustów Forest, the annual deposition of nitrogen is at the level of $10-12 \mathrm{~kg} \cdot \mathrm{ha}^{-1}$ per year (Kasperowicz and Wacław 2016), and this alone suffices to ensure that forests here are different from those from several decades ago. This is particularly true for the older phases of stand development, which historical data reveal as once less resource-rich, with spruce and broadleaved trees absent from lower stand layers, and with ground cover formerly typical of coniferous forest, consisting of a fairly loose cover of bilberry (Ossendowski 1936; Andrzejczyk and Brzeziecki 1995; Szczygielski 2007; Solon and Matuszkiewicz 2008; Paluch and Gabrysiak 2019). This has been documented in Fig. 3.

Today, the ongoing effects of eutrophication in the Augustów Forest include the presence of spruce in what had previously been nutrient-poor site types, with a closed understorey or the second stand layer of this

Table 6 Confusion matrix for the model parametrised by the method of searching all the possible combinations using the AIC criterion AIC (OR = 3.42, Log OR=1.23), 1 - active Key Areas, 0 - abandoned Key Areas

\begin{tabular}{lllll}
\hline Observed & Predicted $\mathbf{1}$ & Predicted $\mathbf{0}$ & Percentage of correct observations \\
\hline 1 & 970 & 54 & Specificity & 91.95 \\
0 & 687 & 61 & Sensitivity & 5.27 \\
\hline
\end{tabular}


species. Succession involving spruce - and even broadleaved trees such as birch and the hazel Corylus avellana - is changing forest structure (including the oldest developmental stages of pine forest) in a manner unfavourable to capercaillies, even where the site had previously been nutrient-poor. This would seem to explain why today's capercaillies in the Augustów Forest most often occupy forest stands that are $30-60$ or $60-100$ years old, and why the phase of development proved to have such a great and significant influence in the context of the overall model. Along the forest age gradient, competition eases and the closure of the stand is more open, which makes it possible for the undergrowth to develop in stands that are $30-60$ years old.

The process referred to here also applies to sites in which lekking of capercaillies takes place. Many descriptions of leks indicate that a great share of old forest is a typical requirement for the species (Gjerde and Wegge 1989; Storch 1993; Swenson and Angelstam 1993; Saniga 1996, 2003). And yet, several studies from more recent decades document the presence of leks in middle-aged stand classes (Picozzi et al. 1992; Miettinen et al. 2010; Sirkiä et al. 2010; Wegge and Rolstad 2011). Our work suggests that the Augustów Forest's active leks are predominantly located in stands which are 30 to 100 years old, not in the oldest parts of stands.

The process of leks in mature ( $>100$ year-old) forest being abandoned by capercaillies has been observable in the Augustów Forest over the last few decades, while new places for the leks have been observed in younger stands (50-60 years old) (Zawadzki et al. 1999; Brzeziecki et al. 2012; Zawadzki and Zawadzka 2012; Zawadzka et al. 2018). Similar trend is visible in commercial forests in South-Eastern Norway, where the formation and establishment of new displaying grounds in stands which are less than 50 years old has been described (Rolstad et al. 2007; Wegge and Rolstad 2011). Positive relationships between the proportion of a forest of younger age classes and the densities of capercaillie populations have been also documented in Finland, where studies suggest that a managed, thinned, middleaged forest (30-40 years and more) is suitable and even has a positive effect on population density at the large scale (Miettinen et al. 2008, 2010). According to Sirkiä et al. (2010), a change of preference regarding stand age can be also indirectly connected with the extent of the fragmentation of the habitat and the spatial distribution of particular patches of a mature forest. Small fragments of old stands occurring as 'islands' surrounded by forest in the youngest age classes do not represent favourable conditions for the species. The importance of connectivity between habitat patches suitable for the capercaillie is also emphasised by Bollmann et al. (2011) as well as Sirkiä et al. (2012). The preferences of the species for the mature forest as once described seem to be most directly associated with the structure rather than age, as evidenced also by more recent publications (Storch 2001, 2007; Watson and Moss 2008; Miettinen et al. 2010).

Researchers had previously confirmed the major importance of bilberry to capercaillies, both as a food plant for adult birds and as places in which the Lepidotera larvae representing food for chicks may develop (Storch 1993; Selas 2000; Gregersen and Gregersen 2008). In the Augustów Forest, the cover of this dwarf shrub was high across the study area, with the effect that this factor was not considered to influence any differentiation between areas still occupied or already abandoned by the birds under study. Indeed, within the analysed areas, the share of the ground covered by bilberry was actually greater in the abandoned Key Areas, perhaps due to the basic fact that the presence of bilberry bushes attracts potentiallydisturbing bilberry-pickers and also ensures a greater intensity of use of certain roads (a variable not taken into account in the optimal model on the basis of the AIC criteria). However, in line with the expectations, Key Areas which were further from roads were those still supporting capercaillies, while the negative influence of human disturbance on the species has been demonstrated with regard to other areas across the range (Summers et al. 2007; Storch 2013; Moss et al. 2014). It is not only forest works that are damaging to the capercaillie; human recreation also has a negative effect (Coppes et al. 2017, 2018).

\section{Conclusions}

Altogether, changes in forest structure at the local (patch) scale are important, though they are probably not the only reasons for the decline in the numbers of the capercaillie. The grouse representing the subject of our study are shown to occupy the dry and poor, middle-aged, pine-dominated, single-layered forest with a much less-diversified habitat mosaic than in other parts of their lowland range. Our research further reveals that over the last few decades the species has abandoned the oldest stands in the Augustów Forest, with leks having been transferred to younger stands. Our analysis based on the logistic regression model points to the cover shares of the two layers of undergrowth as the most important features discriminating those Key Areas for capercaillies that remain active as lekking grounds or else have already been abandoned. Any development of a greater inclusion of trees and shrubs - stimulated by climate changes or the eutrophication of habitats, or in connection with forest management - will do much to reduce the probability of the occurrence of the capercaillie. The lack of natural disturbances also favours the development of a dense layer of undergrowth. The birds' transfer of leks to younger stands is probably associated 
not so much with an age preference as with a specific kind of not-too-dense stand structure. In places where under-layers of vegetation are artificially introduced or appear spontaneously under the canopy of older stands, this process changes the forest structure in a manner unfavourable to the capercaillie. Thus, habitat improvement for the species in question requires that the natural development of the understorey (mainly spruce under the conditions in the Augustów Forest) should be held back, or not introduced at all where this would be an element of managerial measures. Also recommended is the maintenance of a more open stand closure than hitherto, one not exceeding $70 \%$. The logistic regression model based on stand variables is well able to point to habitat that is suitable for capercaillies, even if it is less precise in indicating which habitat features are inappropriate for the species. However, it is strongly recommended that the habitats which the study revealed to be suitable should not be transformed with practical measures.

\section{Authors' contributions}

SD conducted the conception, design of the work, data collection, statistical analysis, data interpretation, draft of the work. DZ conducted the conception, data collection, draft of the work, significant revision, review of the literature. GZ conducted the data collection and analysis, design of graphics, review of the literature. MS conducted the statistical analysis. BB conducted the conception, design of the work, data collection, review of the literature, significant revision. The authors' read and approved the final manuscript.

\section{Competing interests}

The authors declare that they have no competing interests.

\section{Author details}

${ }^{1}$ Institute of Forest Sciences, Warsaw University of Life Sciences, Nowoursynowska 159, 02-776 Warszawa, Poland. ${ }^{2}$ Department of Forest Sciences, University of Łódź, Branch in Tomaszów Mazowiecki, Konstytucji 3 Maja 65/67, 97-200 Tomaszów Mazowiecki, Poland. ${ }^{3}$ Institute of Agriculture, Warsaw University of Life Sciences, Nowoursynowska 159, 02-776 Warszawa, Poland.

Received: 11 January 2021 Accepted: 6 June 2021

Published online: 23 July 2021

\section{References}

Akkaike H (1974) A new look at statistical model identification. IEEE Trans Autom Control 19(6):716-723. https://doi.org/10.1109/TAC.1974.1100705

Andrzejczyk T, Brzeziecki B (1995) The structure and dynamics of old-growth Pinus sylvestris (L.) stands in the Wigry National Park, North-Eastern Poland. Vegetatio 117(1):81-94. https://doi.org/10.1007/BF00033261

Angelstam P (1996) The ghost of forest past-natural disturbance regimes as a basis for reconstruction for biologically diverse forests in Europe. In: DeGraaf RM, Miller RI (eds) Conservation of faunal diversity in forested landscapes. Chapman and Hall, London, pp 287-337. https://doi.org/10.1007/978-94009-1521-3_11

Angelstam P (2004) Habitat threshold and effects of forest landscape change on the distribution and abundance of black grouse and capercaillie. Ecol Bull 51: 173-187

Angelstam P, Roberge J-M, Lõhmus A, Bergmanis M, Brazaitis G, Dönz-Breuss M, Edenius L, Kosiński Z, Kurlavičius P, Lārmanis V, Lukins M, Mikusiński G, Racinskis E, Strazds M, Tryjanowski P (2004) Habitat modelling as a tool for landscape-scale conservation - a review of parameters for focal forest birds. Ecol Bull 51:427-453

Baines D, Summers RW (1997) Assessment of bird collisions with deer fences in Scottish forest. J Appl Ecol 34(4):941-948. https://doi.org/10.2307/2405284
Basile M, Balestrieri R, de Groot M, Flajšman K, Posillico M (2016) Conservation of birds as a function of forestry. Ital J Agro 11:42-48

Basile M, Mikusiński G, Storch I (2019) Bird guilds show different responses to tree retention levels: a meta-analysis. Global Ecol Conserv 18:e00615. https://doi. org/10.1016/j.gecco.2019.e00615

Battles JJ, Shlisky AJ, Barrett RH, Heald RC, Allen-Diaz BH (2001) The effects of forest management on plant species diversity in a Sierran conifer forest. For Ecol Manag 146(1-3):211-222. https://doi.org/10.1016/S0378-1127(00)00463-1

Bollmann K, Graf RF, Suter W (2011) Quantitative predictions for patch occupancy of capercaillie in fragmented habitats. Ecography 34(2):276-286. https://doi. org/10.1111/j.1600-0587.2010.06314.x

Bollmann K, Weibel P, Graf RF (2005) An analysis of Central Alpine capercaillie spring habitat at the forest stand scale. For Ecol Manag 215(1-3):307-318. https://doi.org/10.1016/j.foreco.2005.05.019

Braunisch V, Roder S, Coppes J, Froidevaux JSP, Arlettaz R, Bollmann K (2019) Structural complexity in managed and strictly protected mountain forests: effects on the habitat suitability for indicator bird species. For Ecol Manag 448:139-149. https://doi.org/10.1016/j.foreco.2019.06.007

Braunisch V, Suchant R (2007) A model for evaluating 'habitat potential' of a landscape for capercaillie Tetrao urogallus: a tool for conservation planning. Wildl Biol 13(Suppl.1):21-33. https://doi.org/10.2981/0909-6396(2007)13[21:A MFETH]2.0.CO;2

Broome A, Connolly T, Quine CP (2014) An evaluation of thinning to improve habitat for capercaillie (Tetrao urogallus). For Ecol Manag 314:94-103. https:// doi.org/10.1016/j.foreco.2013.11.038

Brzeziecki B, Drozdowski S, Zawadzka D, Zawadzki J (2012) Quantification of ecological preferences of the Capercaillie Tetrao urogallus by means of the habitat suitability index: a case study in the Augustów Forest. Pol J Ecol 60: 233-242

Bujoczek L, Szewczyk J, Bujoczek M (2018) Deadwood volume in strictly protected, natural, and primeval forests in Poland. Eur J For Res 137(4):401418. https://doi.org/10.1007/s10342-018-1124-1

Burnham KP, Anderson DR (2002) Model selection and multimodel inference. Springer, New York

Coppes J, Ehrlacher J, Thiel D, Suchant R, Braunisch V (2017) Outdoor recreation causes effective habitat reduction in capercaillie Tetrao urogallus: a major threat for geographically restricted populations. J Avian Biol 48(12):15831594. https://doi.org/10.1111/jav.01239

Coppes J, Nopp-Mayr U, Grünschachner-Berger V, Storch I, Suchant R, Braunisch V (2018) Habitat suitability modulates the response of wildlife to human recreation. Biol Conserv 227:56-64. https://doi.org/10.1016/j.biocon.2018.08.018

Cowley MJR, Wilson RJ, León-Cortés $\mathrm{L}$, Gutiérrez D, Bulman CR, Thomas CD (2000) Habitat-based statistical models for predicting the spatial distribution of butterflies and the day-flying moths in a fragmented landscape. J Appl Ecol 37(Supl. 1):60-72

Czeszczewik D, Zub K, Stanski T, Sahel M, Kapusta A, Walankiewicz W (2014) Effect of forest management on bird assemblages in the Białowieza Forest, Poland. iForest 8:e1-e9

Domaniewski J (1933) Materials for distribution of the capercaillie (Tetrao urogallus Linn.) in Poland. Acta Ornithol 1:83-121

Gjerde I, Wegge P (1989) Spacing pattern, habitat use and survival of Capercaillie in a fragmented winter habitat. Ornis Scand 20(3):219-225. https://doi.org/1 $0.2307 / 3676916$

Głowaciński Z (2001) Polish red data book of animals. In: Vertebrates. PWRiL, Warsaw

Graf RF, Bollmann K, Bugmann H, Suter W (2007) Forest landscape structure as prediction of capercaillie occurrence at the forest stand and home range scales. J Wildl Manag 71(2):356-365. https://doi.org/10.2193/2005-629

Graf RF, Bollmann K, Sachot S, Suter W, Bugmann H (2006) On the generality of habitat distribution models: a case study of capercaillie in three Swiss regions. Ecography 29(3):319-328. https://doi.org/10.1111/j.2006.0906-7590. 04328.x

Graf RF, Bollmann K, Suter W, Bugmann H (2005) The importance of spatial scale in habitat models: capercaillie in the Swiss alp. Lanscape Ecol 20(6):703-711. https://doi.org/10.1007/s10980-005-0063-7

Gregersen H, Gregersen F (2008) Old bilberry forest increases likelihood of Capercaillie Tetrao urogallus lek occupancy in southern Norway. Ornis Norv $31(0): 105-115$. https://doi.org/10.15845/on.v31i0.172

Hanley JA, MCNeil BJ (1982) The meaning and use of the area under a receiver operating characteristic curve (ROC). Radiology 143(1):29-36. https://doi.org/1 0.1148/radiology.143.1.7063747 
Hosmer DW Jr, Lemeshow S (1989) Applied logistic regression. Wiley, New York, p 307

Jahren T, Storaas T, Willebrand T, Moa FP, Hagen BR (2016) Declining reproductive output in capercaillie and black grouse - 16 countries and 80 years. Anim Biol 66:363-400

Kämmerlea JL, Braunisch V, Suchant R, Coppes J (2020) Quantifying the effectiveness of habitat management to counter local extinction: a casestudy on capercaillie. For Ecol Manag 474:1 18379. https://doi.org/10.1016/j. foreco.2020.118379

Kasperowicz A, Wacław B (2016) Program Ochrony Środowiska Województwa podlaskiego na lata 2017-2020. Zarząd Województwa Podlaskiego, Białystok

Klaus S, Andreev AV, Bergmann HH, Muller HH, Porkert J (1989) Die Auerhuhner In: Die Neue Brehm-Bucherei. Band 86. Westarp Wissenschaften, Magdeburg

Kleinbaum DG, Kupper LL, Morgenstern H (1982) Epidemiologic research. In: Principles and quantitative methods. Van Nostrand-Reinhold, New York, p 529

Kleyer M, Kratz R, Lutze G, Schröder B (1999) Habitatmodelle für Tierrten: Entwicklung, Methoden und Perspektiven für die Anwendung. Z Ökol Naturschutz 8:177-194

Leivitis M (2014) Characterisation of capercaillie metapopulation spatial structure by means of habitat suitability model. Publ Inst Geogr Univ Tartu 111: 248-261

Lindenmayer D, McCarthy MA (2002) Congruence between natural and human forest disturbance: a case study from Australian montane ash forests. For Ecol Manag 155(1-3):319-335. https://doi.org/10.1016/S0378-1127(01)00569-2

Linder P, Östlund L (1998) Structural changes in three mid-boreal Swedish forest landscapes, 1885-1996. Biol Conserv 85(9):9-19. https://doi.org/10.1016/ S0006-3207(97)00168-7

Löhmus A, Leivits M, Pētrehofs E, Zisas R, Hofmanis H, Ojaste I, Kurlavičius P (2017) The Capercaillie Tetrao urogallus: an iconic focal species for knowledge-based integrative management and conservation of Baltic forest. Biodivers Conserv 26(1):1-21. https://doi.org/10.1007/s10531-016-1223-6

Löhmus A, Löhmus P, Remm J, Vellak K (2005) Old-growth structural elements in a strict reserve and commercial forest landscape in Estonia. For Ecol Manag 216(1-3):201-215. https://doi.org/10.1016/j.foreco.2005.05.031

Merta D, Zawadzka D, Krzywiński A (2015) Effectiveness of capercaillie (Tetrao urogallus) reintroduction projects in Europe. Sylwan 159:863-871

Miettinen J, Hele P, Nikula A, Niemelä P (2010) Capercaillie (Tetrao urogallus) habitat characteristics in north-boreal Finland. Silva Fenn 44:235-254

Miettinen J, Helle P, Nikula A, Niemelä P (2008) Large-scale landscape composition and capercaillie (Tetrao urogallus) density in Finland. Ann Zool Fennici 45(3):161-173. https://doi.org/10.5735/086.045.0301

Mikoláš M, Svitok M, Bollmann K, Reif J, Bače R, Janda P, Trotsiuk V, Čada V, Vítková L, Teodosiu M, Coppes J, Schurman JS, Morrissey RC, Mrhalová HM (2017) Mixed-severity natural disturbances promote the occurrence of an endangered umbrella species in primary forests. For Ecol Manag 405:210218. https://doi.org/10.1016/j.foreco.2017.09.006

Mikoláš M, Svitok M, Tejkal M, Leitão PJ, Morrissey RC, Svoboda M, Seedre M, Fontaine JB (2015) Evaluating forest management intensity on an umbrella species: Capercaillie presence in Central Europe. For Ecol Manag 354:26-34. https://doi.org/10.1016/j.foreco.2015.07.001

Moss R, Leckie F, Biggins A, Poole T, Baines D, Kortland K (2014) Impacts of human disturbance on capercaillie Tetrao urogallus distribution and demography in Scottish woodland. Wildl Biol 20(1):1-18. https://doi.org/10.2 981/wlb.12065

Moss R, Oswald J, Baines D (2001) Climate change and breeding success: decline of the capercaillie in Scotland. J Anim Ecol 70:47-61

Moss R, Storch I, Muller M (2010) Trends in grouse research. Wild Biol 16(1):1-11. https://doi.org/10.2981/09-055

Oliver CD, Larson BA (1996) Forest stand dynamics. Update edition. John Wiley \& Sons, Inc. New York, Chchester, Brisbane, Toronto, Singapore

Ossendowski FA (1936) Polish primeval forests. Wydawnictwo Polskie R, Wegnera

Pakkala T, Pellikka J, Lindén H (2003) Capercaillie Tetrao urogallus: a good candidate for an umbrella species in taiga forests. Wild Biol 9(1):309-316. https://doi.org/10.2981/wlb.2003.019

Paluch R, Gabrysiak KA (2019) Long-term changes of tree species composition in high protective regime stands in the Augustów and Knyszyn forests. Sylwan 163:846-854

Picozzi N, Catt DC, Moss R (1992) Evaluation of capercaillie habitat. J Appl Ecol 29(3):751-762. https://doi.org/10.2307/2404485
Poirazidis K, Bontzorlos V, Xofis P, Zakkak S, Xirouchakis S, Grigoriadou E, Kechagioglou S, Gasteratos I, Alivizatos H, Panagiotopoulou M (2019) Bioclimatic and environmental suitability models for capercaillie (Tetrao urogallus) conservation: Identification of optimal and marginal areas in Rodopi Mountain-Range National Park (Northern Greece). Glob Ecol Conserv. 17:e00526

R Core Team (2019) R: a language and environment for statistical computing. R Foundation for Statistical Computing, Vienna

Reindl A (1965) The Augustów Forest. In: Broda J (ed) History of forest, forestry and the wood industry in Poland. PWRiL, Warsaw

Roberge J-M, Angelstam P (2006) Indicator species among resident forest birds a cross-regional evaluation in northern Europe. Biol Conserv 130(1):134-147. https://doi.org/10.1016/j/biocon.2005.12.008

Rolstad J, Rolstad E, Wegge P (2007) Capercaillie Tetrao urogallus lek formation in young forest. Wildl Biol 13(Suppl. 1):59-67. https://doi.org/10.2981/0909-63 96(2007)13[59:CTULFI]2.0.CO;2

Rolstad J, Wegge P (1987) Distribution and size of capercaillie leks in relation to old forest fragmentation. Oecologia 72(3):389-394. https://doi.org/10.1007/ BF00377569

Rosenvald R, Lõhmus A (2003) Nesting of the black stork (Ciconia nigra) and white-tailed eagle (Haliaeetus albicilla) in relation to forest management. For Ecol Mgmt. 185(3):217-223

Saniga M (1996) Habitat characteristics of capercaillie Tetrao urogallus leks in Central Slovakia. Biologia Bratislava 51:191-199

Saniga M (2003) Ecology of the capercaillie Tetrao urogallus and forest management in relation to its protection in the West Carpathians. J Forest Sci 49:229-239

Scheringer W, Schumacher H (2004) Der Einfluss forstlicher Bewirtschaftungsmaßnahmen auf die Waldvogelwelt - eine Übersicht. Vogelwelt 125:215-250

Selas V (2000) Population dynamics of capercaillie Tetrao urogallus in relation to bilberry Vaccinium myrtillus production in southern Norway. Wildl Biol 6(1):111. https://doi.org/10.2981/wlb.2000.032

Sirkiä S, Helle P, Lindén H, Nikula A, Norrdahl K, Saurosa P, Valkeajärvi P (2011) Persistence of Capercaillie (Tetrao uroagllus) lekking areas depends on forest cover and fine-grain fragmentation of boreal forest landscapes. Ornis Fenn 88:14-29

Sirkiä S, Lehtomäki J, Lindén H, Tomppo E, Moilanen A (2012) Defining spatial priorities for capercaillie Tetrao urogallus lekking landscape conservation in south-Central Finland. Wildl Biol 18(4):337-353. https://doi.org/10.2981/11073

Sirkiä S, Lindén A, Helle P, Nikula A, Knape J, Lindén H (2010) Are the declining trends in forest grouse populations due to changes in the forest age structure? A case study of Capercaillie in Finland. Biol Conserv 143(6):15401548. https://doi.org/10.1016/j.biocon.2010.03.038

Sokołowski AW (2010) Augustów forest. Centrum Informacyjne Lasów Państwowych, Warsaw

Solon J, Matuszkiewicz JM (2008) Changes in phytosociological forest types: directions, causes, and possibility to counteract. In: Mazur S, Tracz H (eds) Anthropogenic threats to forest ecosystems. 8th Symposium of Forest Ecosystem Protection SGGW, Warsaw, pp 56-66

Silvicultural Guidelines (2012) State Forests Information Centre, Warsaw

Storch I (1993) Habitat selection by Capercaillie in summer and autumn: is bilberry important? Oecologia 95(2):257-265. https://doi.org/10.1007/ BF00323498

Storch I (2001) Capercaillie. BWP 3:1-24

Storch I (2002) On spatial resolution in habitat models: can small-scale forest structure explain capercaillie numbers? Conserv Ecol 6(1). https://doi.org/10 5751/ES-00381-060106

Storch I (2007) In: WPA/BirdLife/SSC GGrouse Specialist Group (ed) Grouse Status Survey and Conservation Action Plan 2006-2010. IUCN, Gland, Switzerland and Cambridge, UK and the World Pheasant Association, Reading

Storch I (2013) Human disturbance of grouse - why and when? Wildl Biol 19(4): 390-403. https://doi.org/10.2981/13-006

Summers RW, McFarlane J, Pearce-Higgins J (2007) Measuring avoidance by Capercaillie Tetrao urogallus of woodlands close to tracks. Wildl Biol 13(1):1927. https://doi.org/10.2981/0909-6396(2007)13[19:MABCTU]2.0.CO;2

Suter W, Graf R, Hess R (2002) Capercaillie Tetrao urogallus and avian biodiversity: testing the umbrella-species concept. Conserv Biol 16(3):778-788. https://doi. org/10.1046/j.1523-1739.2002.01129.x 
Swenson J, Angelstam P (1993) Habitat separation by sympatric forest grouse in Fennoscandia in relation to boreal forest succession. Can J Zool 71(7):13031310. https://doi.org/10.1139/293-180

Szczygielski M (2007) Changes in phytosociological features of fresh coniferous forest Peucedano-Pinetum in Piska and Augustowska Forest in span of 50 years. Stud Mat CEPL 9:153-167

Teuscher M, Brandl R, Rösner S, Bufka L, Lorenc T, Förster B, Hothorn T, Müller J (2011) Modelling habitat suitability for the Capercaillie Tetrao urogallus in the national parks Bavarian Forest and Šumava. Ornithol Anz 50:97-113

Thiel D, Jenni-Eiermann S, Palme R, Jenni L (2011) Winter tourism increases stress hormone levels in the Capercaillie Tetrao urogallus. Ibis 153(1):122-123. https://doi.org/10.1111/j.1474-919X.2010.01083.X

Tomiałojć $L$ (2000) Gradient in breeding distribution and species richness of the Europaean woodland avifauna. Acta Ornithol 35:3-17

Watson A, Moss R (2008) Grouse. Collins Publisher, London

Wegge P, Larsen B (1987) Spacing of adult and subadult male common capercaillie during the breeding season. Auk 104(3):481-490. https://doi.org/1 $0.2307 / 4087547$

Wegge P, Rolstad J (2011) Clearcutting forestry and Eurasian boreal forest grouse: long-term monitoring of sympatric capercaillie Tetrao urogallus and black grouse $T$. tetrix reveals unexpected effect on their population performances. For Ecol Manag 261(9):1520-1529. https://doi.org/10.1016/j.foreco.2011.01.041

Wegge P, Rolstad J, Storaunet KO (2013) On the spatial relationship of males "exploded leks": the case of Capercaillie grouse Tetrao urogallus examined by GPS satellite telemetry. Ornis Fenn 90:222-235

Zawadzka D (2014) The handbook of the best practices in protection of the capercaillie and black grouse. Centrum Koordynacji Projektów Środowiskowych, Warsaw

Zawadzka D, Drozdowski S, Zawadzki G, Zawadzki J (2016) The availability of cavity trees along an age gradient in fresh pine forests. Silva Fenn 50(3)

Zawadzka D, Drozdowski S, Zawadzki G, Zawadzki J, Mikitiuk A (2018) Importance of the old forest tree stands for bird diversity in managed pine forests - a case study from Augustów Forest (NE Poland). Pol J Ecol 66(2):162-181. https://doi.org/10.3161/15052249PJE2018.66.2.007

Zawadzka D, Zawadzki J (2003) The capercaillie. In: Natural history monographs 11. Klub Przyrodników, Świebodzin

Zawadzki J, Sudnik W, Zawadzka D (1999) Changes in distribution and numbers of capercaillie, Tetrao urogallus L., in the Puszcza Augustowska forest and a proposal for an active protection of the species. Sylwan 143:69-78

Zawadzki J, Zawadzka D (2008) The population dynamics of capercaillie in the Augustowska Primeval Forest in 1911-2005. In: Lubelski J (ed) Protection of the forest grouse. Post-conference monograph. Centrum Informacyjne Lasów Państwowych, Warsaw, pp 25-34 16-18th October 2007

Zawadzki J, Zawadzka D (2012) Population decline of Capercaillies Tetrao urogallus in the Augustów Forest (NE Poland). Acta Ornithol 47(2):199-204. https://doi.org/10.3161/000164512X662322

Zizas R, Mozgeris G, Baliuckas V, Brazatis G, Belova O, Grašytè G, Kurlavičius P (2017) The effect of forest landscape structure on the location and occupancy of Capercaillie (Tetrao urogallus L.) Leks. Balt For 23:411-422

\section{Submit your manuscript to a SpringerOpen ${ }^{\circ}$ journal and benefit from:}

- Convenient online submission

- Rigorous peer review

- Open access: articles freely available online

- High visibility within the field

- Retaining the copyright to your article

Submit your next manuscript at $\boldsymbol{\nabla}$ springeropen.com 